\title{
A Rare Case of Thrombotic Thrombocytopenic Purpura Caused by Acute Pancreatitis
}

\author{
Emin Gemcioglu, ${ }^{1}$ Mehmet Kayaalp, ${ }^{2}$ Merve Caglayan, ${ }^{2}$ Ahmet Ceylan, ${ }^{2}$ Mehmet Sezgin Pepeler ${ }^{3}$ \\ ${ }^{1}$ Specialist Doctor, Department of Internal Medicine, Ankara City Hospital. \\ ${ }^{2}$ Resident Doctor, Department of Internal Medicine, Yildırım Beyazıt University School of Medicine, Ankara City Hospital. \\ ${ }^{3}$ Specialist Doctor, Department of Internal Medicine, Division of Hematology, Ankara City Hospital. \\ Ankara, Turkey.
}

Acta Gastroenterol Latinoam 2021;51(2):203-206

Received: 09/12/2020 / Accepted: 26/02/2021 / Published online: 21/06/2021 / https://doi.org/10.52787/uhkq1369

\section{Summary}

Thrombotic Thrombocytopenic Purpura is a syndrome of microangiopathic hemolytic anemia accompanied by thrombocytopenia, neurological disorders, renal failure and fever. Acute pancreatitis is a rare cause of Thrombotic Thrombocytopenic Purpura and this manifestation, at the same time, is a rare complication of acute pancreatitis. Thrombotic Thrombocytopenic Purpura is induced in acute pancreatitis by poorly understood mechanism, which involves multiple pathways apart from only ADAMTS-13 deficiency. Here, we analyze the case of a 47-year-old female who presented with an acute pancreatitis. She was diagnosed with Thrombotic Thrombocytopenic Purpura and an acute pancreatitis at the same time, with thrombocytopenia and peripheral smear findings at presentation. Therefore, Thrombotic Thrombocytopenic Purpura secondary to the pancreatitis was considered in this case. In this work, we have discussed details of our case and the different mechanisms involved in pathogenesis of Thrombotic Thrombocytopenic Purpura in acute pancreatitis and their outcome with prompt management.

Keywords. Acute Pancreatitis, thrombotic thrombocytopenic purpura, clopidogrel.

\section{Un caso raro de púrpura trombo- citopénica trombótica causada por pancreatitis aguda}

\section{Resumen}

La púrpura trombocitopénica trombótica es un sindrome de anemia hemolitica microangiopática acompañada de trombocitopenia, trastornos neurológicos, insuficiencia renal y fiebre. La pancreatitis aguda es una causa rara de la púrpura trombocitopénica trombótica. Esta manifestación, al mismo tiempo, es también una complicación rara de la pancreatitis aguda. La púrpura trombocitopénica trombótica se induce en la pancreatitis aguda por un mecanismo poco conocido que involucra múltiples vías además de la 
deficiencia de ADAMTS-13. En el presente trabajo, analizamos el caso de una mujer de 47 años que se presentó con una pancreatitis aguda. Se le diagnosticó una púrpura trombocitopénica trombótica y una pancreatitis aguda al mismo tiempo, con trombocitopenia y hallazgos de frotis periféricos. Por lo tanto, en este caso, se consideró a la púrpura secundaria a la pancreatitis en este caso. Asimismo, desarrollamos en detalle nuestro caso y los diferentes mecanismos involucrados en la patogénesis de la púrpura trombocitopénica trombótica en la pancreatitis aguda y su resultado con un manejo rápido.

Palabras claves. Pancreatitis aguda, púrpura trombocitopénica trombótica, clopidogrel.

\section{Abbreviations}

TTP: Thrombotic Thrombocytopenic Purpura.

ADAMTS-13: A disintegrin and metalloproteinase with a thrombospondin type 1 motif, member 13.

VWFCP: Von Willebrand factor-cleaving protease.

MRI: Magnetic resonance imaging.

CT: Computed tomography.

iv: intravenous.

HIV: Human immunodeficiency virus.

$v$ WF: Von Willebrand factor.

NO: Nitric oxide.

\section{Introduction}

Thrombotic Thrombocytopenic Purpura (TTP) is a syndrome of microangiopathic hemolytic anemia accompanied by thrombocytopenia, neurological disorders, renal failure and fever. ${ }^{1}$ TTP is a disease diagnosed with clinical and laboratory values. Although ADAMTS-13 activity is an important marker, it is not an absolute diagnostic criterion. TTP may be due to congenital ADAMTS-13 total or partial deficiency as well as acquired causes. This case report is about acute pancreatitis, one of the uncommon causes of TTP.

\section{Case report}

A 47-year-old female patient was admitted to the emergency service of our hospital with the complaints of abdominal distension, dyspepsia, and bilious vomiting. The patient had a history of coronary artery disease, hypertension and coronary angiography 15 days ago. The patient was receiving metoprolol and clopidogrel regularly. She had abdominal pain in the epigastric region and vomiting. She also complained of dark urine color. On physical examination, her general condition was moderate; she was conscious, oriented-cooperative, and there was tenderness in the abdomen. There was no defense, no rebound. Petechiae, purpura and ecchymosis were not observed in the inspection performed to detect bleeding disorder. Laboratory analyses were as follows: white blood cell count $=9.200 / \mu \mathrm{L}$; absolute neutrophil count $=5830 / \mu \mathrm{L}$; hemoglobin $=8.4 \mathrm{~g} / \mathrm{dL}$; platelets $=6000 / \mu \mathrm{L}$; urea $=96 \mathrm{mg} / \mathrm{dL}$; creatinine $=1.35 \mathrm{mg} / \mathrm{dL}$; lactate dehydrogenase $>750 \mathrm{U} / \mathrm{L}$; Amylase $=262 \mathrm{U} / \mathrm{L}$; Lipase $=427 \mathrm{U} / \mathrm{L} ; \mathrm{T}$. Bilirubin $=1.9 \mathrm{mg} / \mathrm{dL} ;$ D. Bilirubin $=0.6 \mathrm{mg} / \mathrm{dL} ; \mathrm{I}$. Bilirubin $=1.3 \mathrm{mg} / \mathrm{dL}$; procalcitonin $=0.1 \mu \mathrm{g} / \mathrm{L} ;$ C-reactive protein $=62.5 \mathrm{mg} / \mathrm{L}$; ferritin $=857 \mu \mathrm{g} / \mathrm{L}$; folate $=22 \mathrm{ng} / \mathrm{mL}$; vitamin $\mathrm{B} 12=225 \mathrm{ng} / \mathrm{L}$; reticulocyte $=4.31 \%$; corrected reticulocyte count $=2.4$. ADAMTS-13 activity was found to be low. It was considered that this patient with high lactate dehydrogenase, indirect hyperbilirubinemia, ane$\mathrm{mia}$, and thrombocytopenia may have hemolytic anemia and microangiopathic hemolytic anemia. Therefore, a peripheral smear was performed in which, schistocytes were seen in all areas (Figure 1). The platelet count was found to be ten thousand accordingly. No atypical cells were detected. Abdominal CT was performed to the patient with the prediagnosis of acute pancreatitis. In the abdominal CT of the patient, an increase in pancreatic dimensions in all axes and contamination of the mesenteric fatty tissue in the peripancreatic area were detected (Figure 2). This patient, who met all three of the acute pancreatitis diagnostic criteria (abdominal pain, amylase or lipase elevation and characteristic findings in the taken images) was diagnosed with acute pancreatitis and TTP (secondary to acute pancreatitis). Plasmapheresis treat-

Figure 1. Peripheral Smear Sign Fragmented Erythrocytes

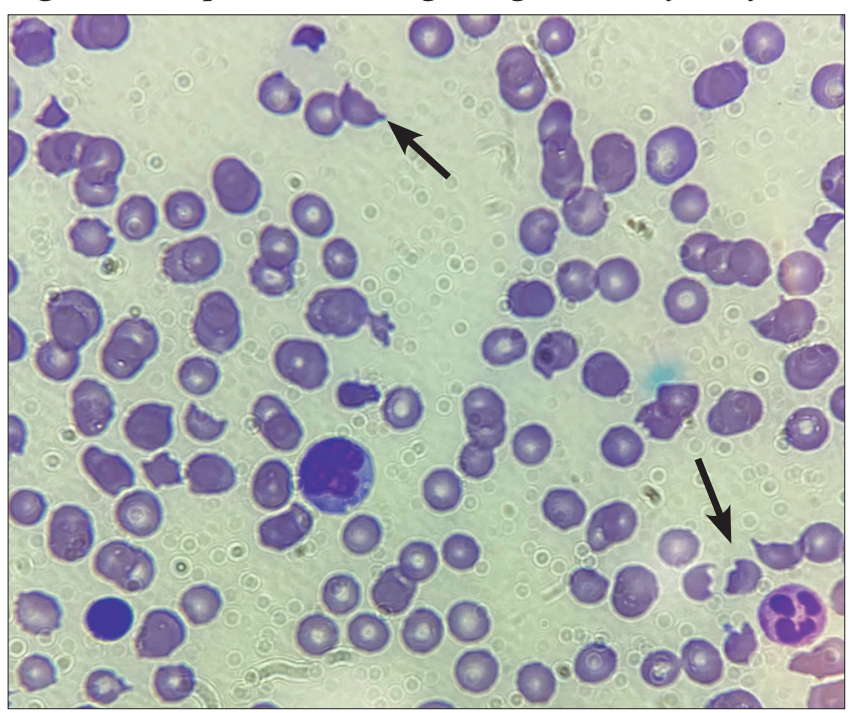


Figure 2. MRI and CECT Abdomen of Patient Showing Interstitial Pancreatitis
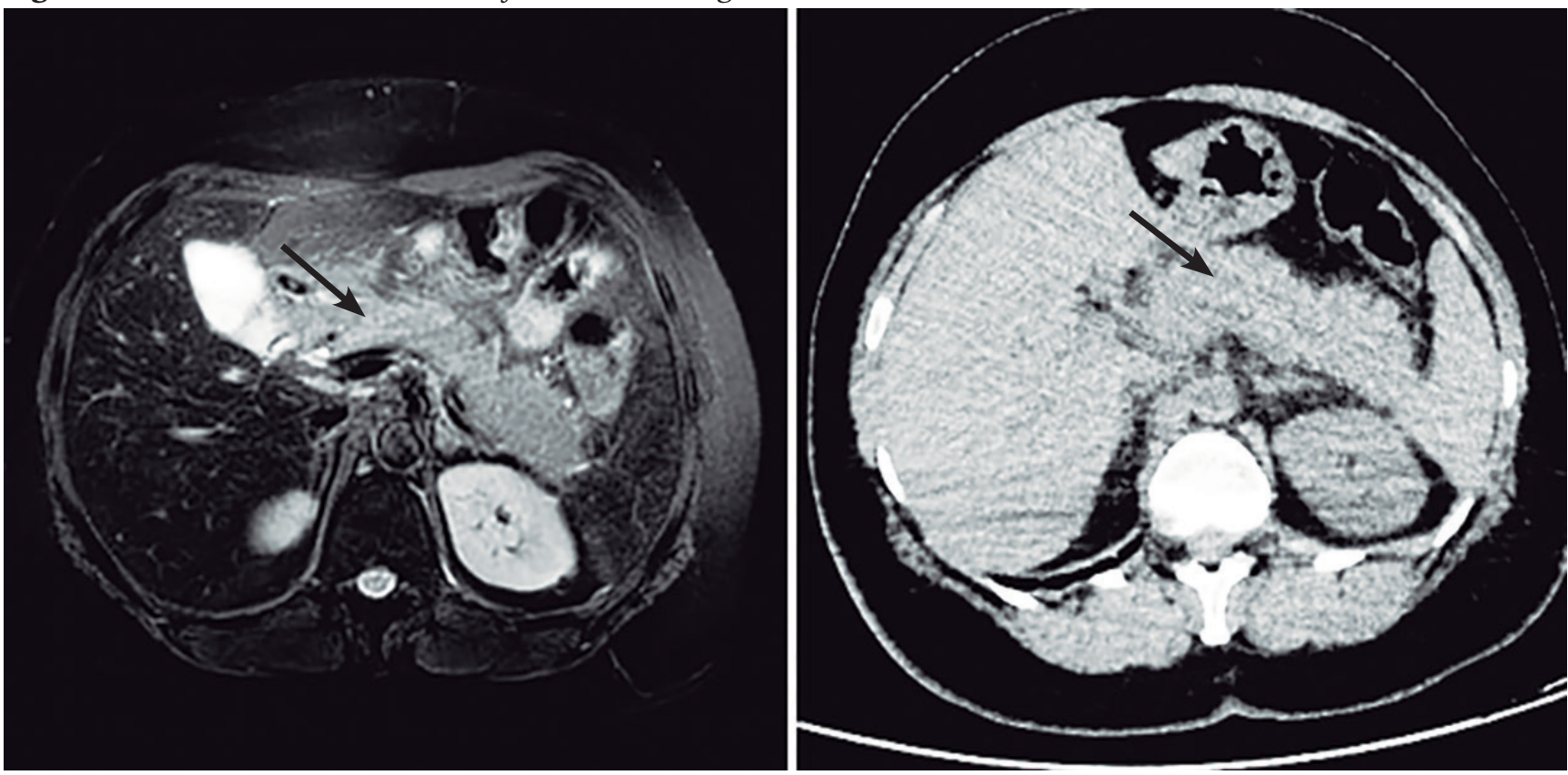

ment with fresh frozen plasma, pain control, and IV fluid treatment was initiated for the patient. She received 5 sessions of plasmapheresis treatment. Hemodialysis was not required in the follow-up of this patient who had high urea and creatinine on admission. The patient's kidney function tests returned to their baseline level. During her follow-up, the platelet value increased to $140,000 / \mu \mathrm{L}$. Abdominal pain recovered, amylase and lipase levels decreased to normal levels.

\section{Discussion}

TTP is a microangiopathic hemolytic anemia syndrome accompanied by thrombocytopenia, neurological disorders, renal failure, and fever. There is a congenital or acquired ADAMTS-13 protease enzyme deficiency in TTP. Acquired TTP is mostly idiopathic and may be due to infections (e.g. hepatitis C, pneumonia, HIV, and sepsis), medications (e.g. mitomycin C), medical procedures (e.g. hematopoietic stem cell transplant) and chronic diseases (e.g. malignancies, cirrhosis, connective tissue disorders, ulcerative colitis, diabetes mellitus, and hyperthyroidism) ${ }^{2}$

Acute pancreatitis is one of the rare causes of TTP. Systemic inflammatory response due to inflammatory cytokines (secondary to acute pancreatitis), microvascular damage caused by the complement system activated by pancreatic enzymes, and ADAMTS-13 deficiency are held responsible in the pathophysiology of this disease. ${ }^{3}$
Inflammatory cytokines caused by acute pancreatitis increase the release of ultra-large vWF multimers, and the decrease in ADAMTS-13 levels prevents these multimers from being cleared by ADAMTS-13.4,5 The reduction of pancreatic endothelial NO synthase enzyme in acute pancreatitis may play a role in the formation of microangiopathies such as TTP., 3

Pancreatitis has been reported as a rare complication $(2 \%)$ in TTP cases in the literature. ${ }^{7}$ Pancreatic involvement was also reported in TTP cases. In a study conducted by Hosler et al., 51 patients diagnosed with TTP were reported to have pancreatic damage on postmortem examination, and the reason for this was impaired pancreatic circulation due to thrombotic occlusions in small vessels. ${ }^{4,8}$ The mean time between the diagnosis of TTP and the diagnosis of acute pancreatitis was reported to be 2-3 days. ${ }^{2,3}$ Our patient was presented with an acute pancreatitis clinic. She was diagnosed with TTP and an acute pancreatitis at the same time, with thrombocytopenia and peripheral smear findings at presentation. Therefore, in this case, TTP secondary to pancreatitis was considered in this case.

Medications are one of the causes of acquired TTP. Drug-related TTP cases have been reported as less than $15 \%$ of all TTP cases. TTP development, due to the use of clopidogrel, begins within 2 weeks and its mortality is around $10-20 \% .^{2}$ Antiplatelet therapy change is required in the treatment and, although, it is a rare condition, it 
should be kept in mind by clinicians that clopidogrel-associated TTP may occur after the coronary intervention.

\section{Conclusion}

In conclusion, repeated plasmapheresis and steroid treatments are used in the treatment of TTP cases due to acute pancreatitis. In the treatment of drug-related TTP, the responsible drug should be changed. The change in antiplatelet therapy, in the treatment of clopidogrel-associated TTP, is vital to avoid life-threatening consequences. Our case is remarkable for clinicians in terms of emphasizing the importance of early diagnosis and treatment of acute pancreatitis and drug-related TTP.

Conflicts of interest. The author(s) declared no potential conflicts of interest with respect to the research, authorship, andlor publication of this article.

Source of funding. The author(s) received no financial support for the research, authorship, andlor publication of this article.

\section{Copyright}

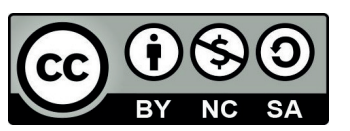

(C) 2021 Acta Gastroenterológica latinoamericana. This is an openaccess article released under the terms of the Creative Commons Attribution (CC BY-NC$S A$ 4.0) license, which allows non-commercial use, distribution, and reproduction, provided the original author and source are acknowledged.
Cite this article as: Gemcioglu E, Kayaalp M, Caglayan M, et al. A Rare Case of Thrombotic Thrombocytopenic Purpura Caused by Acute Pancreatitis. Acta Gastroenterol Latinoam. 2021;51(2):203-6. https://doi.org/10.52787/uhkq1369

\section{References}

1. TTP Diagnosis and Treatment Guide. Available at: http://www. thd.org.tr/thdData/Books/130/bolum-i-trombotik-trombositopenik -purpura-tani-ve-tedavi-kilavuzu.pdf

2. Rawala MS, Naqvi STS, Khan MY, El Toukhy A. A rare Case of thrombotic thrombocytopenic purpura caused by pancreatitis and clopidogrel. Am J Case Rep. 2018;19:1288-91.

3. Gurjar M, Saigal S, Azim A, Mohindra S, Prasad N, Srivastava G. Acute pancreatitis-induced thrombotic thrombocytopenic purpura. JOP. 2012;13(1):80-2.

4. Ali MA, Shaheen JS, Khan MA. Acute pancreatitis induced thrombotic thrombocytopenic purpura. Indian J Crit Care Med. 2014;18(2):107-9.

5. Bergmann IP, Kremer Hovinga JA, Lammle B, Peter HJ, Schiemann U. Acute pancreatitis and thrombotic thrombocytopenic purpura. Eur J Med Res. 2008;13:481-2.

6. Thachil J. Lessons from acute pancreatitis-induced thrombotic thrombocytopenic purpura. Eur J Int Med. 2009;20:739-43.

7. Talwalkar JA, Ruymann FW, Marcoux P, Farraye FA. Recurrent thrombotic thrombocytopenic purpura (TTP) as a complication of acute relapsing pancreatitis. Dig Dis Sci. 2002;47(5):1096-9.

8. Hosler GA, Cusumano AM, Hutchins GM. Thrombotic thrombocytopenic purpura and hemolytic uremic syndrome are distinct pathologic entities. A review of 56 autopsy cases. Arch Pathol Lab Med. 2003;127:834-9. 